\title{
Design of Competitive Processing Plants for Hemp Fibre Production
}

\author{
Ralf Pecenka, Carsten Lühr, and Hans-Jörg Gusovius \\ Leibniz Institute for Agricultural Engineering Potsdam-Bornim (ATB), Max-Eyth-Allee 100, 14469 Potsdam, Germany \\ Correspondence should be addressed to Ralf Pecenka, rpecenka@atb-potsdam.de
}

Received 27 April 2012; Accepted 10 June 2012

Academic Editors: C. B. Pandey and A. K. Patra

Copyright () 2012 Ralf Pecenka et al. This is an open access article distributed under the Creative Commons Attribution License, which permits unrestricted use, distribution, and reproduction in any medium, provided the original work is properly cited.

Despite an annually growing demand for natural fibres accompanied by worldwide increasing fibre prices as well as long tradition and experience in fibre processing, the production facilities for hemp and flax fibres are very limited in Europe. At present, the lack of modern harvesting and economic processing technologies seem to be the greatest obstacles for hemp fibre producers under the changing conditions of international raw material markets. Therefore, detailed investigations of all process stages of hemp fibre processing have been carried out at the Leibniz Institute for Agricultural Engineering (ATB). A novel hemp processing line has been developed, installed, and tested at industrial scale in the last 3 years. Investigations regarding optimum plant layout have shown that a straw throughput of approximately $4 \mathrm{t} \mathrm{h}^{-1}$ is required for economic fibre production for all new processing lines at currently high straw prices of more than $150 € \mathrm{t}^{-1}$. Throughputs in the range from 4 to $6 \mathrm{t} \mathrm{h}^{-1}$ showed a favourable relation between profit and investment cost. At throughputs higher than $6 \mathrm{t} \mathrm{h}^{-1}$, the profit per ton processed straw can be further increased. But investment and straw logistic cost increase at these high-throughput levels often much faster.

\section{Current Situation and Purpose of Research}

Resulting from limited fossil resources, global warming, and increasing competition for arable land, there is an increasing demand for renewable raw material from agriculture. Automotive and building industries are traditional customers for the agricultural processing plants supplying high-quality hemp and flax fibres. Presently, more than $23000 \mathrm{t}$ of natural fibres are used annually in the European automotive industry alone. Typically, fibres are used for indoor applications such as seat coverings, door panels, and insulation materials [1]. Future applications of natural fibres will highly depend on the costs of agricultural production and the costs of fibre straw processing. Efficient technologies are already employed for cultivation of hemp and flax in agriculture $[2,3]$ and in the fibre fleece and composite industry. But there is a substantial need for powerful technologies for fibre straw processing to ensure a reliable resourcing of high-quality fibres from agriculture. Therefore, a complete new machine line has been developed and tested at the Leibniz Institute for Agricultural Engineering (ATB) [4].

\section{New Technology for Fibre Straw Processing}

A pilot plant for bast fibre processing with a capacity of up to $3 \mathrm{th}^{-1}$ hemp straw has been developed and evaluated with partners from industry at the ATB (Figures 1 and 2). In this plant innovative technologies have been applied for bale opening, decortication, fibre cleaning, andhurd cleaning [4]. With the same technology, retted and unretted fibre straw from hemp, flax, and oilseed flax can be processed to highquality fibres for technical applications. Experiments with hemp and flax have shown that the excellent decortication quality achieved by this technology essentially simplifies the cleaning process. Thus, a reduction of the cleaning line to a 2 -staged process is feasible (hurd content approx. 2\% ATB line, traditional lines $>7 \%$ ).

In existing plants, long processing lines are related to high investment cost, low mass flows and a high susceptibility to operational problems (Figure 2(a)). The new decortication machine developed at the ATB using impact stress to brake the connection between fibres and hurds is the key to solving operational problems encountered in existing processing lines [5]; see Figure 2(b). 


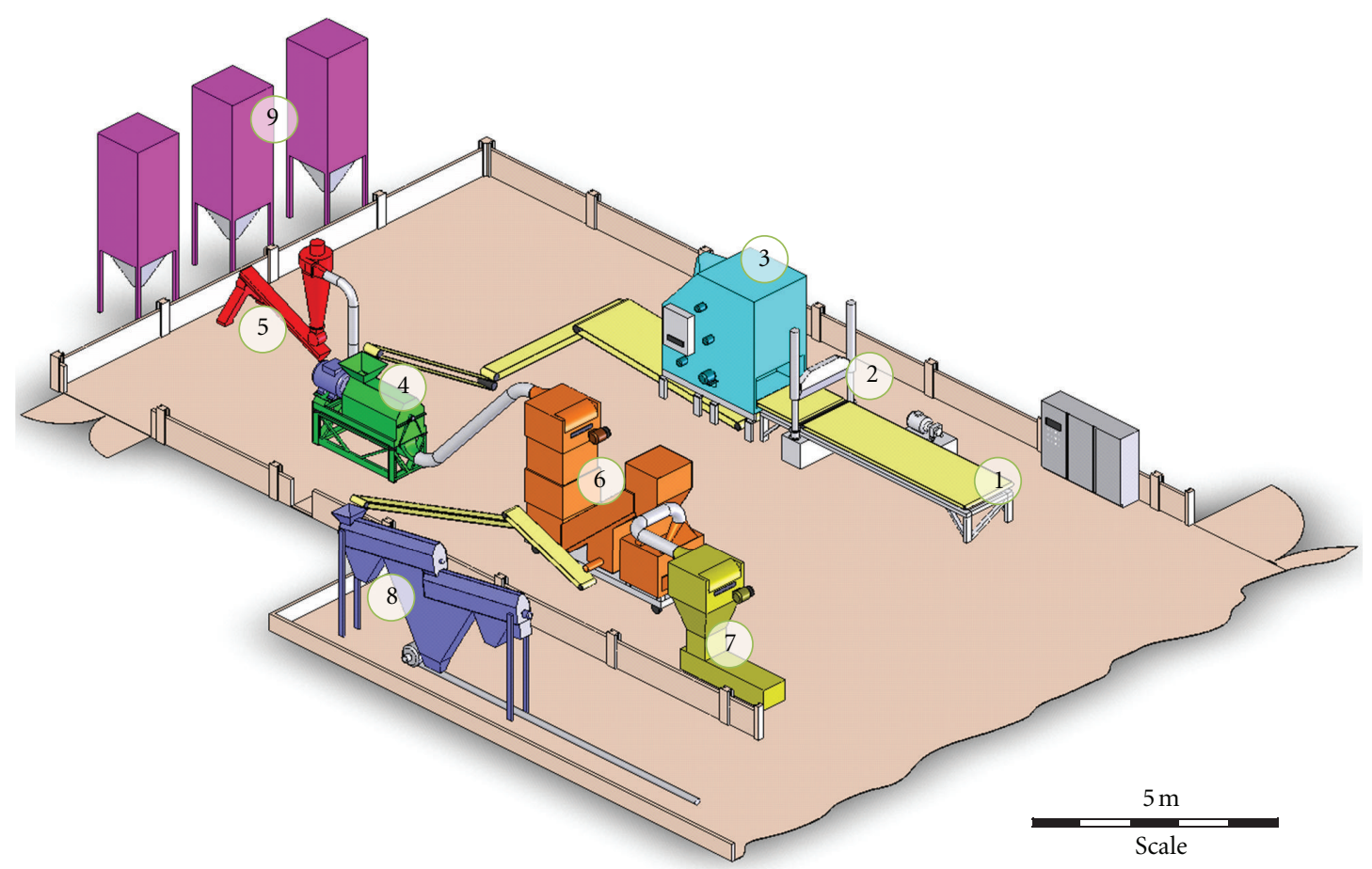

(1) Bale feeder

(2) Bale/straw cutter

(3) Straw opener

(4) Decortication

(5) Dust separation

(6) Fibre cleaning

(7) Fibre baler

(8) Hurd/shive cleaning

(9) Air cleaning

Figure 1: ATB pilot plant for hemp and flax processing.

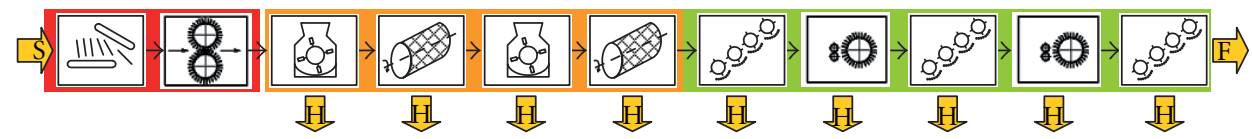

(a) Modern hammer mill line

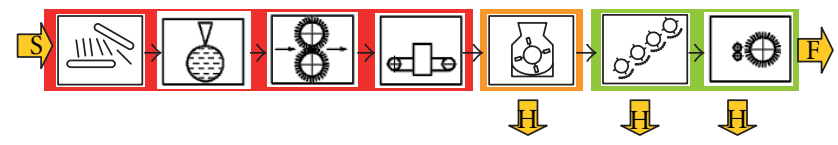

\begin{tabular}{ll}
\hline Straw preparation & S) Straw \\
Decortication & F $)$ Fibres \\
Fibre cleaning & H Hurds/shives
\end{tabular}

(b) ATB processing Line

FIGURE 2: Industrial processing lines for short fibres from hemp and flax. 
TABLE 1: Model parameters for the calculation of profitability of fibre processing plants (subset of main parameters).

\begin{tabular}{ll}
\hline & Technical data \\
\hline $1-8 \mathrm{t} \mathrm{h}^{-1} \mathrm{~d} . \mathrm{m}$. & Hemp straw throughput \\
$25 \%$ & Fibre yield \\
$55 \%$ & Hurd yield \\
$80 \%$ & Running time \\
$5-8$ & Employees for two shifts \\
\hline & Economic data \\
\hline $140-170 € \mathrm{t}^{-1} \mathrm{~d} . \mathrm{m}$. & Straw price for hemp \\
$0.15 € \mathrm{kWh}^{-1}$ & Energy price \\
$0.55 € \mathrm{~kg}^{-1}$ & Fibre price \\
$0.15-0.28 € \mathrm{~kg}^{-1}$ & Hurd price \\
$390,000-820,000 €$ p.a. Labour costs & Specific straw transport cost \\
$0.75 € \mathrm{t}^{-1} \mathrm{~km}^{-1}$ & $\quad$ Investment \\
\hline & $\begin{array}{l}\text { Equipment costs per ton straw throughput } \\
\text { (average at } 5 \mathrm{th}{ }^{-1} \text { throughput) }\end{array}$ \\
\hline $550,000 € \mathrm{t}^{-1} \mathrm{~h}^{-1}$ & Financing \\
\hline $50 \%$ & Financed from credit \\
$4 \%$ & Interest rate \\
& (10 years duration of the credit) \\
\hline
\end{tabular}

\section{Development of a Model for the Evaluation of Fibre Processing Plants}

Long-term praxis experiences with the ATB-hemp processing line between the years 2008 and 2011 as well as information from other hemp processors have been used to evaluate the economy of hemp fibre production. Using the detailed information about all process stages of the entire hemp processing line, an economic feasibility study was carried out applying the European economic conditions [6]. An overview of the most important input factors of this economic study is given in Table 1. On the basis of technical, performance, and financial data, the profit per ton processed hemp straw has been calculated for different plant sizes and variable straw prices.

Earlier studies have shown that profitable fibre production on the basis of hemp straw prices from 90 to $110 € \mathrm{t}^{-1}$ needs a straw throughput of more than $2.5 \mathrm{t} \mathrm{h}^{-1}$ fibre straw [7]. Currently, for quality hemp straw prices ranging from 140 to $160 € \mathrm{t}^{-1}$ have to be paid to the farmers because of increased prices of main crops such as grain, rape seed, and maize.

Because raw material price is one of the most important input variables, a comprehensive investigation of the agricultural process chain of hemp straw production, storage, and transport has been carried out. Hemp cropping is still a niche branch in agriculture, and special knowledge as well as special machinery is required [8]. In the last 20 years praxis experiences have shown that a close cooperation of hemp processors with the local farmers is a prerequisite for success in the long-term. Straw processors need a reliable supply of high-quality straw to fulfil attractive long term contracts

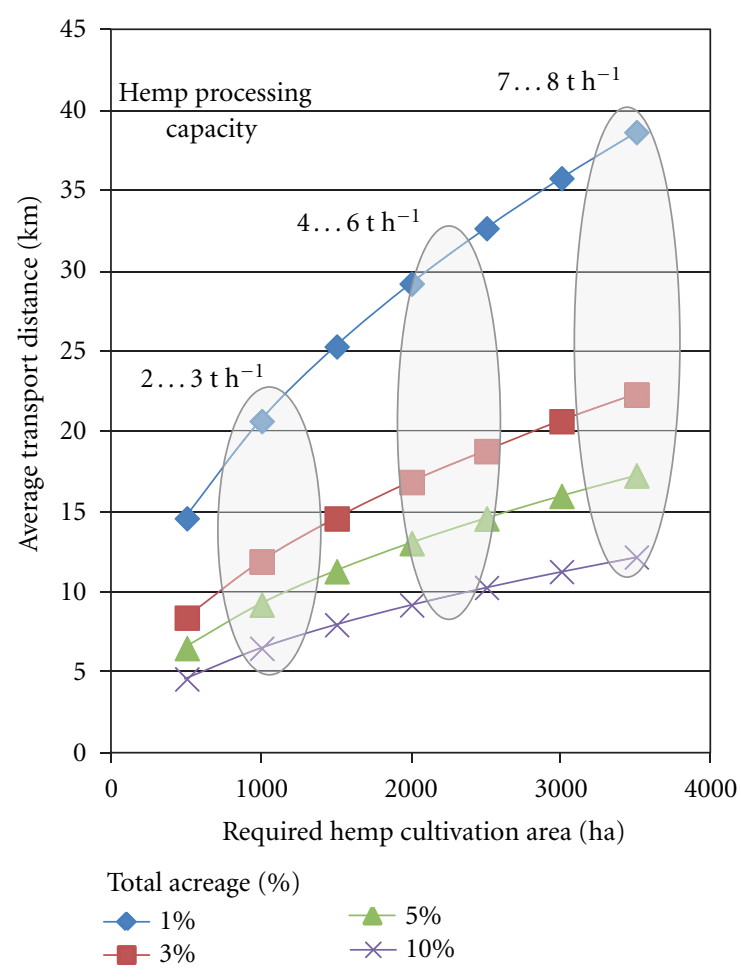

FIGURE 3: Average transport distance in dependence to the required acreage for the supply of processing plants with capacities from 2 to $8 \mathrm{t} \mathrm{h}^{-1}$ hemp straw.

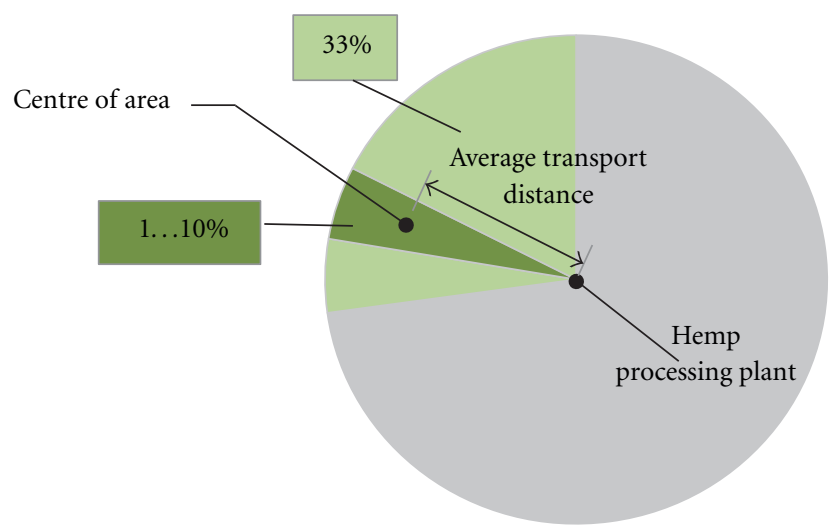

Model region

Share of arable land in the model region

Hemp acreage as a share of the arable land

Figure 4: Average transport distance for hemp straw transport from agricultural storages to the processing plant.

with, for example, the automotive industry. On the other hand, farmers need reliable industrial straw purchasers to invest in special equipment for economic straw production. Without the regional cooperation of both partners, the niche character of hemp fibre production cannot be overcome and transport cost stay an important cost factor. The dependence of transport distances and the allocated share of crop land for hemp straw production in the region of a hemp processing 


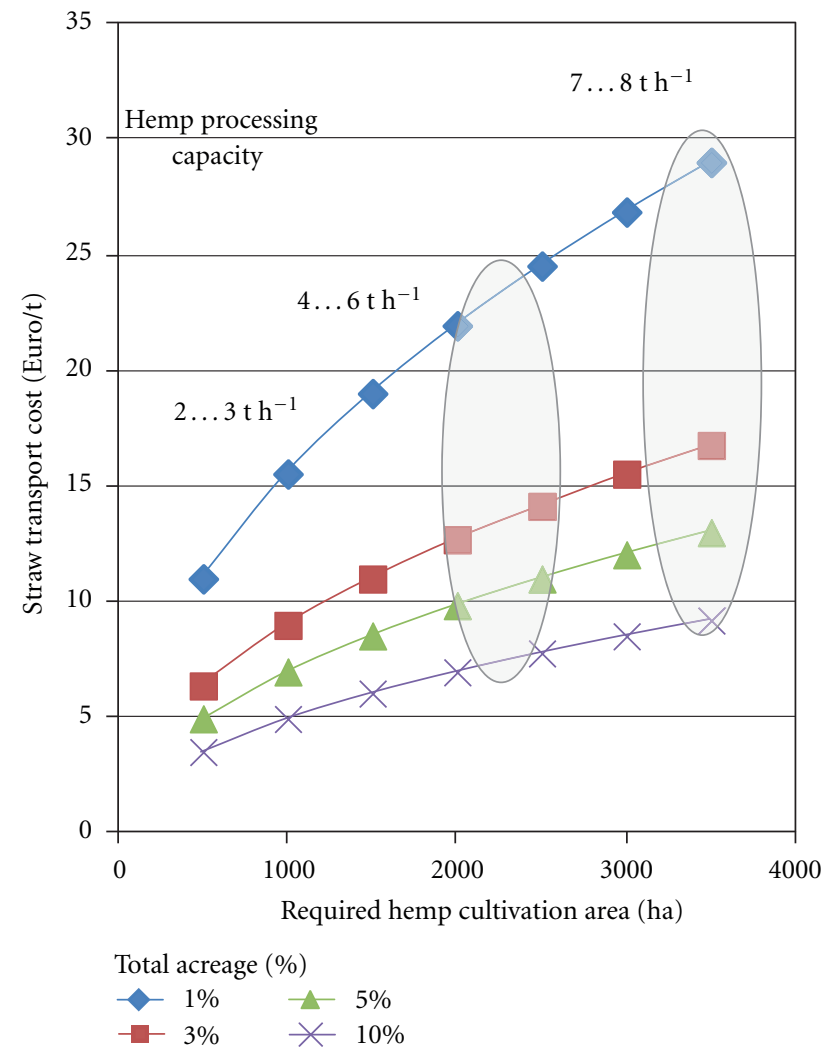

FIGURE 5: Straw transport costs in dependence of the required acreage for the supply of processing plants with capacities from 2 to $8 \mathrm{t} \mathrm{h}^{-1}$ hemp straw.

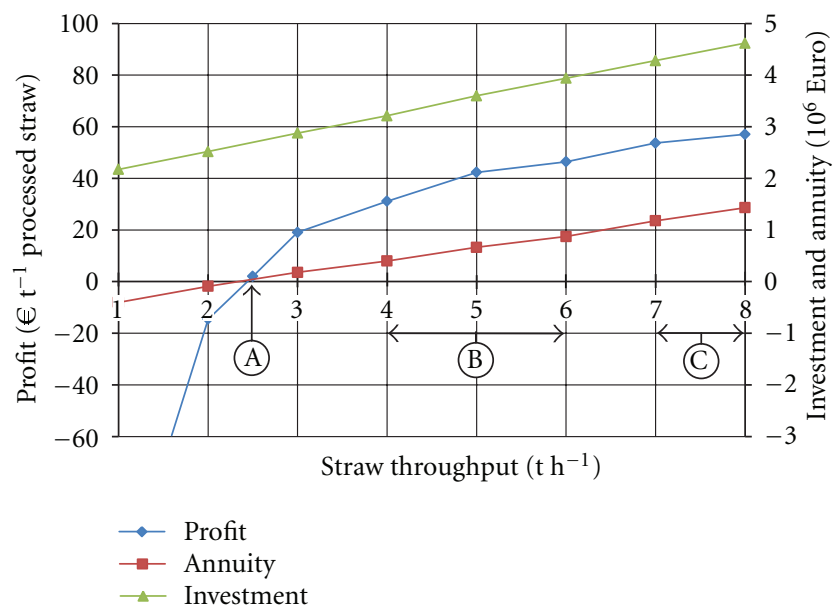

FIGURE 6: Profit for hemp processing with the ATB-processing plant in dependence to straw throughput. A: break even B: optimum relation between plant investment, straw logistic costs and profit $\mathrm{C}$ : increased profit at higher investment and straw logistic costs.

plant has been investigated (Figure 3). The average transport distance has been calculated on the basis of the proportion of the arable land on the total area in a model region (e.g., Germany 33\% [9]), the assumed proportion of hemp cultivation area of the arable land (1-10\%), and the resulting centre of area of the hemp acreage which can used for hemp cropping in the model region (Figure 4).

\section{Results and Conclusions}

On the basis of the specific straw transport costs (Table 1), an average straw yield of $7 \mathrm{t} \mathrm{ha}^{-1}[2,3]$ and the modelled average transport distances typical cost for straw transport can be calculated. Figure 5 illustrates the transport costs in dependence to the required acreage for continuous supply of a hemp processing plant.

Beside the demands on product quality, a processing capacity of more than $2.5 \mathrm{t} \mathrm{h}^{-1}$ fibre straw and a high operational availability are essential requirements for profitable fibre production (Figure 6, A: break even). According to the results of the economic feasibility study, modern processing plants with capacities of $5 \mathrm{t} \mathrm{h}^{-1}$ could generate a profit of approx. $40 €$ per ton processed hemp straw at straw prices of $155 € \mathrm{t}^{-1}$ and costs for straw transport from 7 to $13 € \mathrm{t}^{-1}$. Bigger processing plants with capacities up to $8 \mathrm{th}^{-1}$ can increase their profit to approx. $55 € \mathrm{t}^{-1}$. However, also the required investment increases up to more than 4.5 million Euro. For the supply of such bigger processing plants, almost the double hemp cultivation area is required and higher transport costs often have to be accepted (Figure 5). To reduce this disadvantage the close cooperation with farmers is of highest importance for the economic success. Otherwise, the higher profit will be easily used up by higher transport cost at calculated levels of 17 to $29 € \mathrm{~h}^{-1}$ and more.

Finally, a straw throughput of more than $4 \mathrm{t} \mathrm{h}^{-1}$ is the basis for economic fibre production for all new processing lines at current straw prices of more than $150 € \mathrm{t}^{-1}$. As a consequence of the results shown in Figures 5 and 6 , the design of a hemp processing line made for a straw throughput of approx. $5 \mathrm{th}^{-1}$ will be the target for next machine developments in cooperation with partners from industry.

\section{References}

[1] M. Carus, C. Gahle, D. Pendarovski et al., Studie zur Marktund Konkurrenzsituation bei Naturfasern und NaturfaserWerkstoffen (Deutschland und EU), Fachagentur für Nachwachsende Rohstoffe, Gülzow, Germany, 2008.

[2] T. Graf, G. Reinhold, A. Biertümpfel, and W. Zorn, Leitlinie Zur Effizienten und Umweltverträglichen Erzeugung Von Faserhanf, Thüringer Landesanstalt für Landwirtschaft, Jena, Germany, 2005.

[3] F. Desanlis, "Basics of hemp growing," in Proceedings of the 4th International Conference of the European Industrial Hemp Association, Hürth, Germany, November 2006.

[4] C. Fürll, R. Pecenka, and B. Bojdzinski, "The Potsdam-Bornim plant for Separation of natural fibre with a new technology for cleaning and sizing of shives," in Proceedings of the International Conference on Flax and other Bast Fibers, Saskatoon, Canada, July 2008.

[5] F. Munder, C. Fürll, and H. Hempel, "Results of an advanced technology for decortication of hemp, flax and linseed," Molecular Crystals and Liquid Crystals, vol. 418, pp. 165-179, 2004. 
[6] R. Pecenka, C. Fürll, H. J. Gusovius, and T. Hoffmann, "Optimal plant lay-out for profitable bast fibre production in Europe with a novel processing technology," Journal of Biobased Materials and Bioenergy, vol. 3, no. 3, pp. 282-285, 2009.

[7] R. Pecenka, "Cost reductions in natural fibre processing by the use of an optimized comb shaker for fibre cleaning," Agricultural Engineering Research, vol. 10, pp. 48-53, 2004.

[8] H. J. Gusovius and J. Paulitz, "Current developments for efficient raw material supply procedures enforcing cost-effective bast fibre production in Europe," Journal of Biobased Materials and Bioenergy, vol. 3, no. 3, pp. 262-264, 2009.

[9] Statistisches Jahrbuch, "Statistisches Jahrbuch über Ernährung," Landwirtschaft und Forsten, Landwirtschaftsverlag Münster, Hiltrup, Germany, 2011. 


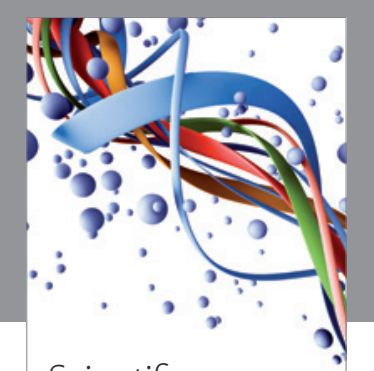

Scientifica
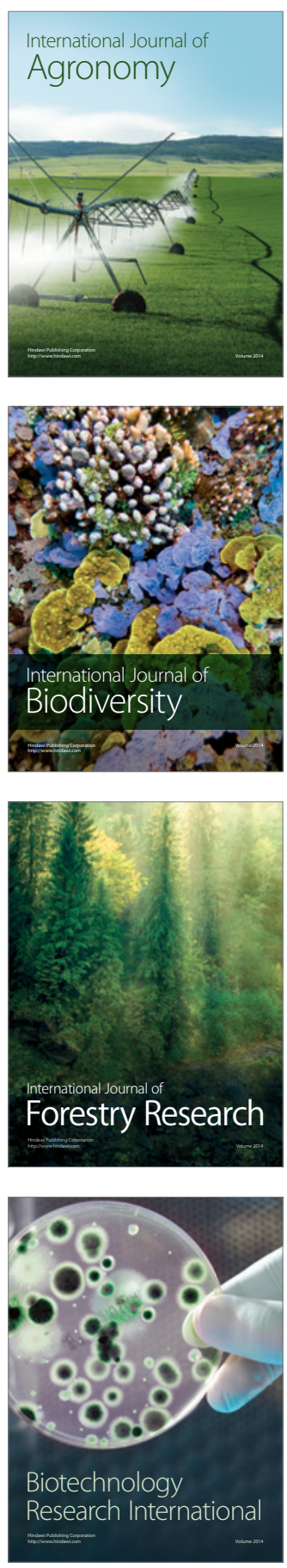
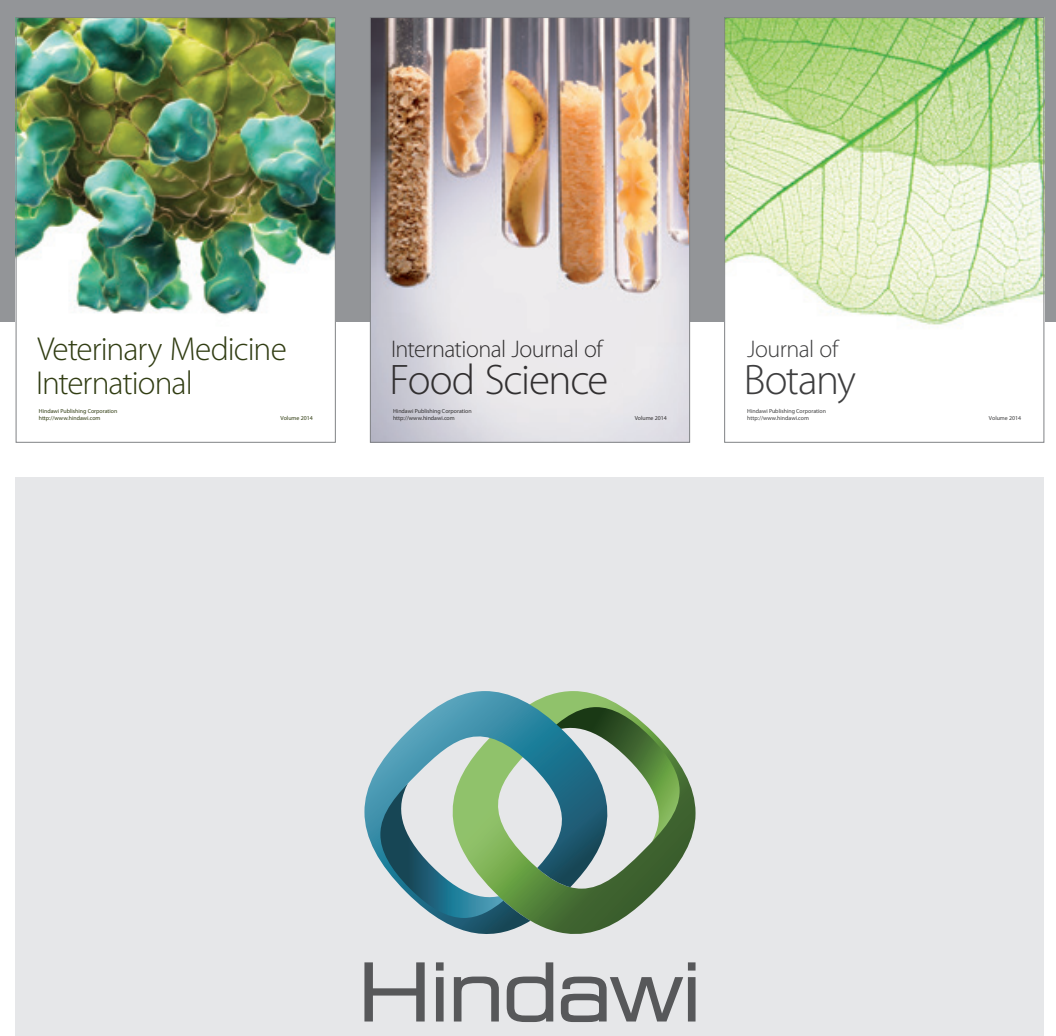

Submit your manuscripts at

http://www.hindawi.com
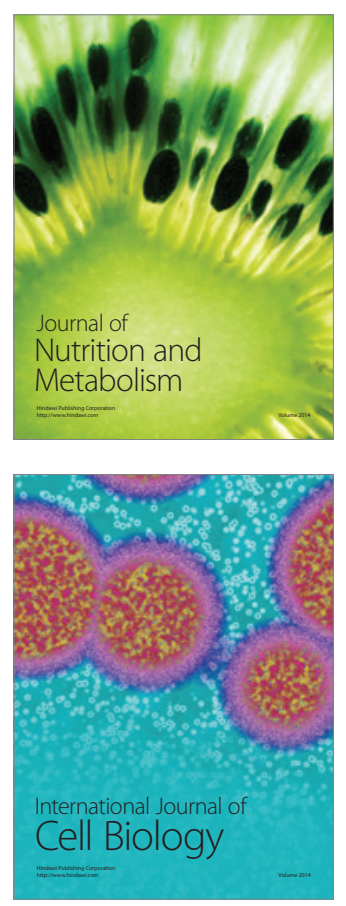
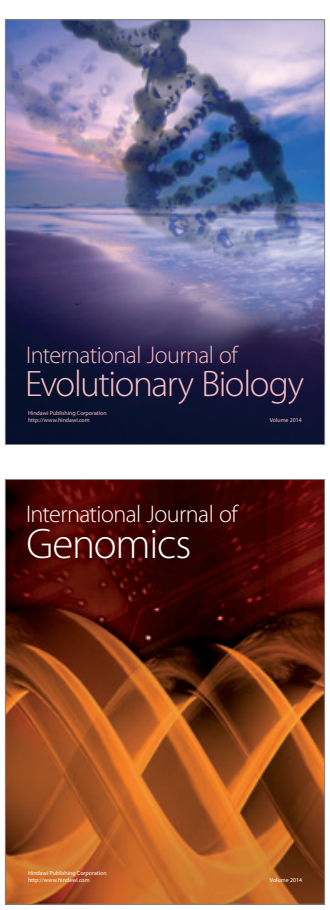
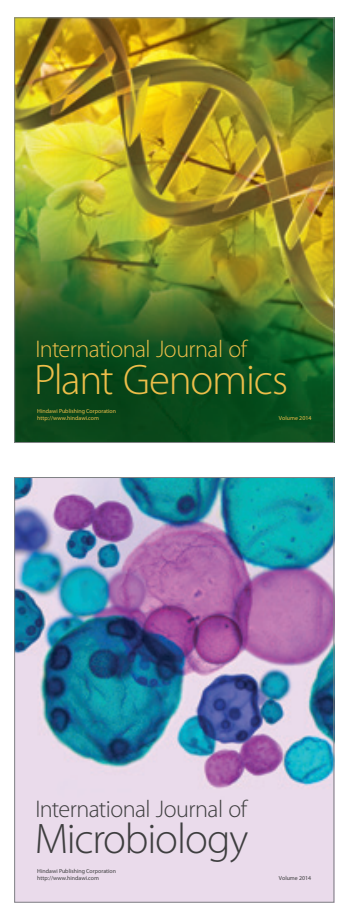

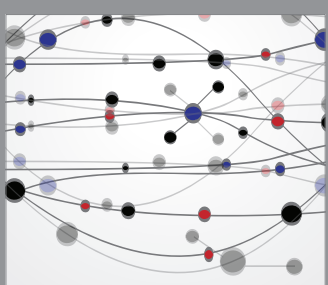

The Scientific World Journal
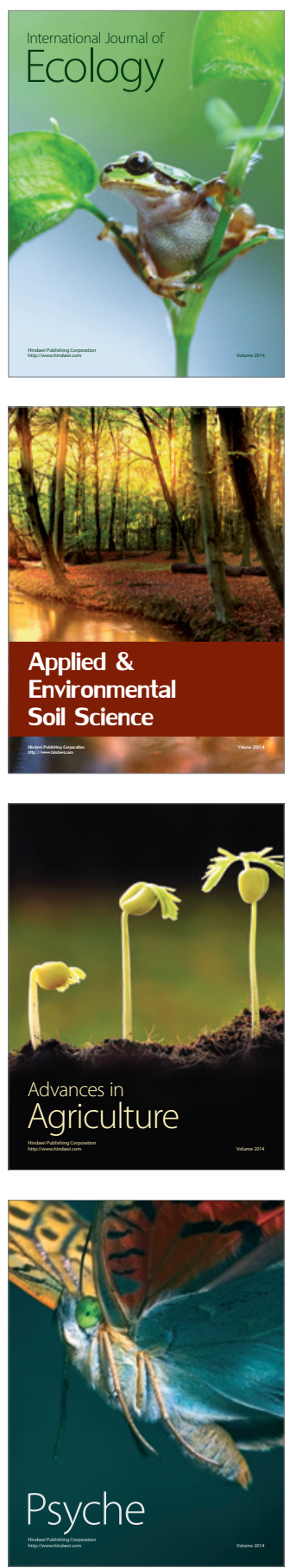